\title{
Critical Analysis of the Factors Affecting the Dividend Payout: Evidence from Pakistan
}

\author{
Saghir Ahmed ${ }^{1}$, Hasan Murtaza ${ }^{2}$ \\ ${ }^{1}$ Department of Management Sciences, National University of Modern Languages, Islamabad, Pakistan \\ ${ }^{2}$ Business School, University of Lahore, Islamabad Campus, Pakistan
}

Email address:

Saghir.numl@gmail.com (S. Ahmed),h95pk2005@gmail.com (H. Murtaza)

To cite this article:

Saghir Ahmed, Hasan Murtaza. Critical Analysis of the Factors Affecting the Dividend Payout: Evidence from Pakistan. International Journal of Economics, Finance and Management Sciences. Vol. 3, No. 3, 2015, pp. 204-212. doi: 10.11648/j.ijefm.20150303.17

\begin{abstract}
The research was conducted to highlight the determinants of dividend payout and to analyse the effect of change in dividends over the future company growth in Pakistan. Firm size, liquidity, profitability, leverage, and earnings per share were used as independent variable while dividend payout ratio was taken as dependent variable. Prolonging this relationship further, dividend payout ratio was taken as independent variable and company growth as dependent variable to examine the impact of dividend payout ratio on future company growth. Descriptive statistics and pooled least square method were used. Eviews was used to process the secondary data from 2003-2011 related to 38 selected companies from four different sectors. Results show that there is a significant relationship among liquidity, earning per share, leverage, firm size and dividend payout ratio in all four selected sectors: Oil, Cement, Energy, and Sugar. It is also found that there is significant relationship between dividend payout ratio and future company growth.
\end{abstract}

Keywords: Dividend Payout, Pooled Least Square Regression, Pakistan

\section{Introduction}

Dividend payout decision making has gained a great interest for financial experts because of its impact on business. It has an effect on the share price and companies future growth (Twaijry, 2007). Management always looks for the forces which influence the dividend payout decisions. Before stepping ahead it is not worthless to define dividend and dividend payout ratio (DPR). Amidu and Abor (2006) defines that the income distributed to shareholders is called dividend, while dividend payout ratio is the proportion of the dividend per share and earnings per share.

In modern corporate finance, dividend payout decisions are associated with the Miller and Modigilani (MM, 1961). This theory presented by Miller and Modigilani which is called MM irrelevance theory based on assumptions of perfect market. They argued that dividend payout has no effect on price of the firm's stock while bird in the hand theorem explains that the relationship between the dividend payout and firm value depends upon the preference of the investor towards monitory benefits. It is because of the riskiness of the future capital gains, so most of the investors usually like to get dividends in short run. Furthermore, tax theory also influences the preference of the investors and they like to less dividend payouts than the capital gains.

Another author gives the dividend puzzle theory in which he argues the more we look deeper into it the more difficult puzzle it becomes with pieces does not fit together. Ahmed and Javid (2009) explain in their article that Pakistan is an emerging economy and there are many important features for examining the dividend payment policy of Pakistani firms. Many researchers concluded that during high growth, companies are likely to pay stable dividend. Here payment of dividend is voluntarily and companies believe stock appreciation as one of the major component of stock returns.

Dividend payout takes influence from couple of variables which are investigated by many researchers in different countries and economies; like ownership structure, profitability, leverage, firms size, growth, liquidity, business risk, trend of past and future prospects ( Ho, 2003; Aivazian, 2003; Najjar, 2009;Amidu and Abor, 2006; Abor and Fiador, 2013). Considering all the write-up, it is important to analyse the variables which affect the dividend payout decisions in companies in different sectors in Pakistan. 


\subsection{Determinants of Dividend Payout}

It is discussed above that there are couple of variables which affect the dividend payout ratio. Brief explanation of some variables is given here.

\subsection{Profitability}

Profitability is the backbone of every business whether it is small or big. All the operational activities depend upon profit which company generates. In case of low profitability, firms cannot perform actively. It has a significant effect on the dividend payout decisions. When company earns well, it can decide to offer higher dividend to shareholders who are the actual owners of the company. Here researcher is taking profitability as the return on assets (ROA).

\section{ROA $=$ Net Income $/$ Total Assets}

Previous research also explored the relationship between dividend payout and profitability. Amidua and Abor (2006) and Najjar (2009) found in his research that like in the developing countries, dividend payment in companies of Jordan is also effected by profitability. Kun Li and ChungHua (2012) asserted that firm's profitability and size significantly affect the payout ratio.

\subsection{Liquidity}

It is one of the important factors being considered in dividend payout decisions because dividend payment generates cash outflow. Greater liquidity shows that company has good cash flows and most probably it can announce higher dividends. When company goes through the development process; mostly it becomes hard to offer dividends. Most often, companies with greater size tend to offer more dividends because of the strong liquidity position.

\section{Current Ratio $=$ Current Assets $/$ Current Liabilities}

Komrattanapanya and Suntrauk (2013) found that dividend payout ratio and liquidity have insignificant relation. While John and Muthusamy (2010) concluded that there is a significant relationship between dividend payout and liquidity. Ahmed and Javid (2009) elaborate that liquidity position is an important determinant of dividend payout.

\subsection{Leverage}

Debt always has a high risk because after all it has to be returned back. Now it depends upon management; how to utilize it. Companies which use high debt in their capital structure tend to pay less dividends while the firms with low debt are tend to pay higher dividends. It is because of firms with high leverage need to protect their creditors and other cash out-flows. Literature also shows that there is a significant relationship between leverage and dividend payout ratio. John and Muthusamy (2010) found that companies tend to pay more dividends with high leverage. Furthermore, Essa (2012) also found that there is a negative relationship between dividend and debt ratio.

\subsection{Growth}

Growth signaling theory elaborates that it is easy for higher growth firms to pay smooth dividends instead of the companies still investing on the growth opportunities. Nissim and Ziv (2001) conducted research to analyse the change in dividend and afterwards change in profitability/growth. He concluded that the dividend changes are positively related with changes in the profitability.

\subsection{Firm Size}

Most often, companies with big size and good cash flows offer higher dividends than the companies of small size. As Najjar (2009) investigated in Jordan and concluded that in developing countries firm size affects the dividend payout decisions. Another research conducted by Perretti, Allen and Weeks (2013) and concluded that the firm size partially explains the dividend policies.

\subsection{Earnings per Share (EPS)}

This is one of the important measures of the firm's profitability. It is being taken because dividends are paid out of the net earnings. So, first from the total earnings, interest, tax and depreciation is subtracted then net earnings are divided over number of shares to find out EPS.

\section{Prior Research}

Twaijry, (2007) conducted research in Malaysia on dividend policy and payouts. He elaborated that, this form of market requires a special dividend policy that may differ from those, used in developed or developing market. He took sample of 300 Malaysian listed companies on the Kuala Lumpur Stock Exchange and several factors including Net EPS, book value of share, company size, company age, past dividends, and past and future earnings were considered. Correlation and mean comparison analyses were employed to examine the possible effect of these factors. He concluded that the current dividends take affect from past and future prospects. Dividends are associated with earnings but to less extent. Payout ratios do not have a strong effect on the company future earnings growth, but had some significant negative correlation with the company's leverage.

Najjar (2009) conducted research in Jordan and used dividend per share, leverage, earning per share, institutional ownership, return on equity, and business risk as variables. He concluded that "the factors which affect the likelihood of dividend payment are similar to those which affect the dividend policy". Finally, the results show that the Lintner model is valid for Jordanian data, and that Jordanian firms have target payout ratios and that they adjust to their target relatively faster than firms in more developed countries. John Lintner (1956) having a great contribution in finding dividend behavior and policy of the firms; he concluded that current earnings and lagged dividend are considered in dividend decision makings. He surveyed 600 firms and 28 firms in complete detail on the basis of discussions from top 
officers and develops a model known as Lintner's model. His model was additionally extended by many researchers that include Fama and Babik (1968) in which they removed added lagged profits and constant in that model which helps to improve results in the model.

Nikolaos (2005) concluded that Greek firm's prefer to pay constant amount of dividend which is adjacent according to their firm's size each year. The data was taken from Athens stock exchange from period 1996-2001. Sample consists of 149 firms over the period of 5 years. Key variables of interest were distributed earnings, sales and current dividend to past dividend. Ahmed and Javid (2009) in Dynamics and determinants of dividend policy of Pakistani firms observed 320 non-financial firms by testing them with Lintner's modified model concluded that firms rely on past dividend and current earnings for their dividend policy. They took dividend yield as dependent and firm's earnings as independent variable.

Al-Najjar (2009) concludes that reasons influencing dividend policy in developed countries are same as in Jordan. He practiced pooled and panel Logit and Tobit Models on non-financial 86 firms in Jordan. Desai, Foley and Hines (2001) disclose that majority-owned foreign members of American corporations show similar dividend policy as of local companies paying dividends to diffused common shareholders. Musa \& Fodio (2009) studied dividend behavior of Nigerian firms; he concluded that earlier dividends, current earnings, cash flow, investment and net current assets have significant impact on dividend policy. Dividend stability has been witnessed by Al-Yahyaee, Pham and Walter (2010) in Oman by working on a particular sample firms using Lintner's model.

Eriotis (2005) studied in Greece about the effects of distributed earnings, size of the firm and changes in dividend and distributed earnings from the previous year. Data comprises of a sample of 149 firms for a period of 5 years. Firms prefer to distribute each year a rather constant dividend, by adjusting to distributed earnings and size. Abor and Bopkin (2010) observed effects of investment opportunities and some other financial variables including some macro variables (inflation rate and GDP) as control variables. Study is based upon a sample of thirty four developing market countries, including Pakistan, for a period of seventeen years from 1990-2006. They found significant relationship between potential investment opportunity and dividend policy.

Salam et al., (2008) inspected in Egypt for a pooled data of 50 firms for 3 years using Logit and Tobit Models. He found significant link between institutional ownership \& dividend policy and insignificant for board composition. Abor and Fiador (2013) investigated the dividend policy patterns with respect to the corporate governance. They used the sample of 27 Ghanaian, 177 Nigerian firms, 51 Kenyan firms and 270 South African firms. Simulations panel regression was used. He concluded that board composition and board size are positively related with dividend payout in Kenya and Ghana respectively. Institutional ownership positively influences dividend payout among Kenyan and South African firms.

Yahyaee, Pham and Walter (2010) conducted research in Oman - Muscat Securities Market over the period 1989-2004 to see the dividend stability. He observed that there are some important features that make Oman a unique and interesting environment to examine the stability of dividend policy. There is no tax charged over the amount of dividend and companies are using high leverage. Companies borrow from Banks and Banks regularly pay visits to borrows so they are known about the borrowers and place of business. Furthermore, they receive mortgage amounts monthly.

Another research conducted by Perreti, Allen and Weeks (2013) in U.S and used multinomial logit regression Model to measure the likelihood of dividend payers and possibility to increase, decrease or no change upon the identified amounts. He concluded that profitability and home country macroeconomic conditions significantly affect the decision to change their dividend policies. Some of the companies tend to use more debt which mean; those firms also need more liquid assets. John and Muthusamy (2010) investigated the leverage, growth and profitability as the determinants of the dividend payout ratio. Ordinal least regression was used. Growth in sales, Earnings per share, Price earnings ratio, Market value to book value, Cash flow, Leverage, Liquidity and Return on assets were used as independent variables while dividend payout was the dependent variable. He concluded that "the results imply that the Indian paper industry employs more leverage for narrating dividend payout ratio".

Essa et al., (2012) investigated dividend policy in Jordan. He took net cash flows, earnings before interest and tax, earning per share, price to book value ratio, dividends yield, and firm size as independent variables and dividend payout policy as dependent variable. A multivariate regression analysis was used to examine the data. Results show that "Earnings per share have the highest effect on dividends, then dividends yield and then price to book value ratio. The study also found a negative relationship between dividends and debt ratio. Final result indicated that large firms have a greater impact on dividends policy decisions than small firms."

Komrattanapanya and Suntrauk (2013) investigated the factors which influence the dividend payout in the all firms listed in the Thailand Stock Exchange. Tobit regression analysis was used. He concluded that "Financial leverage, investment opportunities, and sales growth negatively affect dividend payout; on the other hand, size of firm is positively affected dividend payout. However, it is found that profitability, liquidity, and business risk are insignificantly related to dividend payout"

When company changes dividend payout ratios, it effects the company growth. Growth means the firm earnings/profitability. Nissim and Ziv (2001) conducted research to explore the relation between dividend change and future profitability. He found that "dividend changes provide information about the level of profitability in subsequent years, incremental to market and accounting data. We also 
document that dividend changes are positively related to change in earnings in each of the two years after the dividend change".

\section{Research Methodology}

In the underlying study descriptive statistics was used to calculate the mean, median, standard deviation and skewness. Panel data technique was used to process the data and variables analysed sector by sector. Secondary data was taken from year 2003 to 2011 related to 38 selected companies from four sectors; Cement, Sugar, Energy and Oil.

\subsection{Theoretical Framework}

$$
\text { Independent Variables Dependent variable }
$$

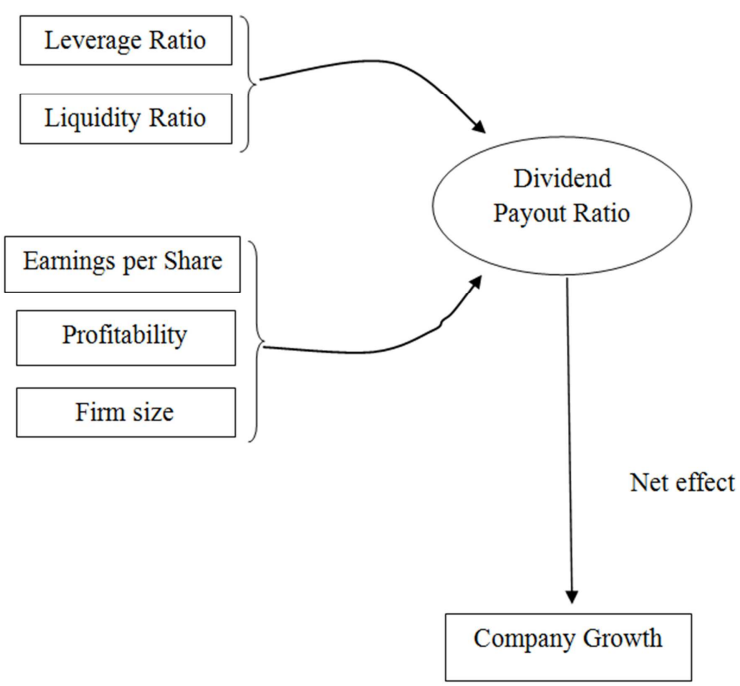

Figure 1. Relationship among variables.

\begin{tabular}{|c|c|c|}
\hline Variable & Definition & Measurement \\
\hline Leverage ratio & Portion of debt used by the company in its capital structure. & $\{$ Short term Debt + Long term debt $\} /$ Equity \\
\hline Liquidity ratio & $\begin{array}{l}\text { Extent to which a company has cash to meet short term obligation or } \\
\text { assets that can be converted into cash easily. }\end{array}$ & Current Assets / Current Liabilities \\
\hline Profitability ratio - ROA & Income earned to utilize the company assets & Net Income / Total Assets \\
\hline Earnings Per Share - EPS & $\begin{array}{l}\text { The portion of companies profit allocated to each outstanding share } \\
\text { of common stock. }\end{array}$ & $\begin{array}{l}\{\text { Net income }- \text { Dividend on preferred stock }\} / \\
\text { Outstanding shares }\end{array}$ \\
\hline Firm Size & Circle of company operational activities & Total sales \\
\hline Company Growth & Change in company sales with the change in DPR & Sales difference \\
\hline
\end{tabular}

Table I. Definition and measurement of dependent and independent variables.

\subsection{Regression Equation}

Following equation has been developed on the basis of the relationship between the dependent and independent variables.

$$
\mathrm{CG}=\mathrm{f}(\mathrm{DPR})
$$

Here,

$\mathrm{CG}=$ Company growth

$\mathrm{DPR}=$ Dividend payout ratio

But

$$
\mathrm{DPR}=\mathrm{f}(\mathrm{PRFT}, \mathrm{LIQD}, \mathrm{LVRG}, \mathrm{FZ}, \mathrm{EPS})
$$

Here,

PRFT $=$ Profitability

LIQD $=$ Liquidity position

$\mathrm{LVRG}=$ Leverage
$\mathrm{FZ}=$ Firm size

EPS $=$ Earnings per share

Now by putting the values of dividend payout ratio (DPR) from Equation \# 2 in equation \# 1

$$
\mathrm{CG}=\mathrm{f}(\text { PRFT, LIQD, LVRG, FZ, EPS) }
$$

So the final equation

$$
\begin{gathered}
\mathrm{CG}=* \beta 1(\mathrm{PRFT})+\beta 2(\mathrm{LIQD})+\beta 3(\mathrm{LVRG})+\beta 4(\mathrm{FS})+ \\
\beta 5(\mathrm{EPS})+\mathrm{e}
\end{gathered}
$$

* Here

$\beta$ is the vector of regression coefficients which we may want to calculate.

This would be proved in the entire four sectors in which researcher is interested to analyse the variables. 


\section{Results}

Descriptive statistics was also calculated of each sector which shows the mean, median, standard deviation, kurtosis and Skewness. These were calculated to assess the variation in the data from the mean. In all four sectors, some variable have normal variation but others have too much. It signifies; the variables which lie near to mean are in small values otherwise variables having bigger values spread out far from center. All these methods actually measure level of uncertainty. According to the descriptive analysis companies in sugar sector are paying highest dividend which is $9.1 \%$ of the total earning per share and lowest is being in the cement sector. The analysis also shows that higher dividend paying firms are using high level of leverage which is $95 \%$ in sugar sector while it's less in the companies which offers low dividends as it is $24 \%$ in cement sector. Table II shows the description of variables in Energy sector. Table III shows the description of variables in Oil sector. Table IV shows the description of variables in Cement sector. Table V shows the description of the variables in Sugar sector.

Table II. Descriptive statistics of the energy sector.

\begin{tabular}{lllllll}
\hline & Mean & Maximum & Minimum & Std. Dev. & Skewness \\
\hline DPR & 0.002 & 0.012 & -0.012 & 0.004 & -0.644 & 1.558 \\
FS & 21.495 & 02.09 & 0.000 & -10.900 & 9.887 & -0.010 \\
EPS & 3.874 & 18.600 & 0.000 & 0.948 & 4.516 & 1.691 \\
LVRG & 0.345 & 4.663 & -10.000 & 7.282 & 1 & -0.024 \\
PFBTY & 2.213 & 15.200 & 1.446 & 14.438 & 1.795 \\
LQTY & 12.851 & 71.933 & & 8.098 & \\
\hline
\end{tabular}

Table III. Descriptive statistics of the Oil Sector.

\begin{tabular}{lllllll}
\hline & Mean & Maximum & Minimum & Std. Dev. & Skewness & Kurtosis \\
\hline DPR & 0.039 & 0.471 & -0.015 & 0.1038 & 11.56 \\
FS & 6.3232 & 10.3234 & 0.000 & -26.48 & 47.97 & 0.407 \\
EPS & 19.07 & 18.160 & 0.000 & 22.171 & 0.940 \\
LVRG & 0.090 & 0.875 & -32.43 & 0.230 & 2.963 \\
PFBTY & 28.583 & 49.40 & 0.000 & 74.43 & 5.097 \\
LQTY & 2.111 & 4.512 & & 1.275 & 10.725 & 0.502 \\
\hline
\end{tabular}

Table IV. Descriptive statistics of the Cement Sector.

\begin{tabular}{|c|c|c|c|c|c|c|}
\hline & Mean & Maximum & Minimum & Std. Dev. & Skewness & Kurtosis \\
\hline DPR & 0.001 & 0.046 & 0.100 & 0.019 & 5.423 & 40.018 \\
\hline FS & 51.44 & 26.40 & 0.000 & 52.789 & 1.428 & 5.006 \\
\hline EPS & -17.347 & 27.100 & -11.700 & 13.407 & -5.367 & 37.550 \\
\hline LVRG & 0.240 & 0.629 & 0.000 & 0.162 & 0.348 & 2.341 \\
\hline PFBTY & 2.253 & 34.00 & -36.000 & 13.13 & 0.269 & 3.899 \\
\hline LQTY & 1.853 & 4.384 & 0.000 & 0.780 & 1.205 & 4.928 \\
\hline
\end{tabular}

Table V. Descriptive statistics of the Sugar Sector.

\begin{tabular}{lllllll}
\hline & Mean & Maximum & Minimum & Std. Dev. & Skewness \\
\hline DPR & 0.091 & 0.100 & -0.049 & 0.014 & 3.403 \\
FS & 28.97 & 24.49 & 0.000 & 31.621 & 4.217 \\
EPS & -17.34 & 32.500 & -20.200 & 9.144 & 0.732 \\
LVRG & 0.95 & 0.753 & 0.000 & 0.662 & 3.31 \\
PFBTY & 5.16 & 4.800 & -14.400 & 11.916 & 0.759 \\
LQTY & 1.97 & 8.030 & 0.000 & 1.396 & 1.134 \\
\hline
\end{tabular}

\subsection{Energy Sector}

Various options of panel data was run through the pooled ordinary least square method. Dividend payout ratio regressed against the five explanatory variables include firm size (Total sales), Earning per share, Leverage, profitability and liquidity of the companies. Table VI shows that in the energy sector, there is significant and positive relationship between the earning per share, leverage, Firm size and liquidity, and dividend payout ratio. It elaborates that the companies in the energy sector are tend to offer more dividends with high EPS and using more leverage, liquidity and firm size.
Furthermore, it is found that there is a negative but significant relationship between the profitability and dividend payout ratio. Here, the value of R-Square which actually shows the effect of the independent variables over the dependent variable. In the Energy sector, dividend payout ratio takes about $56 \%$ influence of the independent variables. With the calculated beta coefficients the regression equation is.

$$
\begin{gathered}
\mathrm{CG}=* \beta 1-0.0003+\beta 23.3900+\beta 30.001+\beta 42.30+ \\
\beta 50.0004+\mathrm{e}
\end{gathered}
$$


Table VI. Pooled least square regression results-Energy sector.

\begin{tabular}{lllll}
\hline Variable & Coefficient & Std. Error & t-Statistic & Prob. \\
\hline FS & 2.300 & 2.030 & 1.134 & 0.265 \\
EPS & 0.000 & 0.000 & 2.236 & 0.033 \\
LVRG & 0.001 & 0.000 & 2.297 & 0.029 \\
PFBTY & 0.000 & 0.000 & -0.938 & 0.356 \\
LQTY & 3.390 & 2.930 & 1.157 & 0.256 \\
R-squared & 0.560 & & & \\
Mean D. variable & 0.002 & & & \\
S.D. dependent Var. & 0.004 & & & \\
\hline
\end{tabular}

Hypothesis 1: To accept or reject the hypothesis which proves the nature of relationship between the dependent and independent variables. We compare the $\mathrm{P}$-value with the Alpha value. In case of earning per share and leverage the null hypothesis is rejected because the $P$ value is less than the alpha value $(0.05)$ and the $\mathrm{HI}$ is accepted.

Ho- there is no significant relationship between independent and dependent variable.

H1- there is a significant relationship between independent and dependent variable.

On the contrary, the null hypothesis is accepted in case of profitability, firm size and liquidity while $\mathrm{HI}$ is rejected (as shown in Table VI).

Hypothesis 2: Yes as it is found in the hypothesis 1 that there is a statistically significant and positive relationship among the earning per share, leverage and dividend payout ratio. Therefore, it is found that when the companies in the energy sector will earn well by using the more leverage in their capital structure then there capacity to pay dividends will also increase. Hence the $\mathrm{Ho}$ is rejected and $\mathrm{Hi}$ is accepted.

Ho- if the company has the more liquid assets, profits, earning per share, leverage and big company size then its capacity to pay dividend will not increase.

HI- if the company has the more liquid assets, profits, earning per share, leverage and big company size then its capacity to pay dividend will increase.

In case of profitability, there is a negative and insignificant relationship but in case of firm size and liquidity there is positive but insignificant relationship so the Ho is accepted while Hi is rejected.

\subsection{Cement Sector}

Results elaborate that there is a statistically significant relationship between liquidity position and dividend payout ratio. It means, the cement sector companies with good liquidity position tend to offer higher dividend. In case of firm size (sales), EPS profitability there is a positive but insignificant relationship while in case of leverage there is a negative and insignificant relationship. Here R- square value shows the effect of independent variables which the dependent variable take. In the cement sector, there is about $72 \%$ effect of the independent variables over the dividend payout ratio. By using the beta coefficients (shown in Table VII) the regression equation is.

$$
\begin{gathered}
\mathrm{CG}=* \beta 11.930+\beta 20.001+\beta 3-0.002+\beta 43.1400+ \\
\beta 51.1000+\mathrm{e}
\end{gathered}
$$

Table VII. Pooled least square regression results-Cement Sector.

\begin{tabular}{lllll}
\hline Variable & Coefficient & Std. Error & t-Statistic & Prob. \\
\hline FS & 3.140 & 9.340 & 0.336 & 0.738 \\
EPS & 1.100 & 4.290 & 0.257 & 0.798 \\
LVRG & 1.930 & 4.780 & 0.403 & 0.687 \\
PFBTY & -0.003 & 0.003 & -1.025 & 0.308 \\
LQTY & 1.100 & 0.000 & 2.884 & 0.005 \\
R-squared & 0.072 & & & \\
Mean D. variable & 0.002 & & & \\
S.D. dependent Var. & 0.006 & & & \\
\hline
\end{tabular}

Hypothesis 1: As there is a positive and significant relationship between the liquidity and dividend payout ratio because of the value of $p$ is less than the alpha value. Hence null hypothesis is rejected while the HI is accepted but in case of rest of the variables the null hypothesis is accepted while HI is rejected.

Ho- there is no significant relationship between independent and dependent variable.

Ho- there is a significant relationship between independent and dependent variable.

Hypothesis 2: As it is concluded above that there is a significant relationship between the liquidity and dividend payout ratio. It means that companies in the cement sector with high liquidity tend to offer more dividends than the other companies. Hence the null hypothesis is rejected while the HI is accepted but in case of the other variables null hypothesis is accepted while $\mathrm{HI}$ is rejected.

Ho- if the company has the more liquid assets, profits, earning per share, leverage and big company size then its capacity to pay dividends will not increase.

HI- if the company has the more liquid assets, profits, earning per share, leverage and big company size then its capacity to pay dividends will increase.

\subsection{Sugar Sector}

Results show that there is a statistically significant and positive relationship between the firm size, profitability and dividend payout ratio while there is a negative and significant relationship between earning per share and dividend payout ratio. It means, the companies in the sugar sector with good profitability, big firm size and liquidity position are offering higher dividend. On the contrary, there is also a negative and insignificant relationship between the leverage, and dividend payout ratio. R-square value shows the effect of independent variable over the dependent variable is 0.40 . It means there is about $40 \%$ influence on the dividend payout ratio by the firm size, earning per share, profitability, leverage and liquidity position of the companies in the sugar sector. Hence the regression equation is.

$$
\begin{gathered}
\mathrm{CG}=* \beta 10.001+\beta 20.001+\beta 3-0.008+\beta 41.530+\beta 5- \\
0.00127+\mathrm{e}
\end{gathered}
$$


Table VIII. Pooled least square regression results - Sugar sector.

\begin{tabular}{lllll}
\hline Variable & Coefficient & Std. Error & t-Statistic & Prob. \\
\hline FS & 1.530 & 4.270 & 3.582 & 0.001 \\
EPS & -0.001 & 0.000 & -4.667 & 0.000 \\
LVRG & -0.008 & 0.005 & 1.564 & 0.121 \\
PFBTY & 0.001 & 0.000 & 4.863 & 0.000 \\
LQTY & 0.001 & 0.001 & 1.873 & 0.064 \\
R-squared & 0.402 & & & \\
Mean D. variable & 0.005 & & & \\
S.D. dependent Var. & 0.015 & & & \\
\hline
\end{tabular}

Hypothesis 1: Results shown in Table VIII explains that there is a significant and positive relationship among the firm size, profitability and dividend payout ratio because the pvalue is less than the alpha value (0.05). Hence the null hypothesis is rejected and $\mathrm{HI}$ is accepted while in the case of the other variables null hypothesis is accepted and HI rejected.

Ho- there is no significant relationship between independent and dependent variable.

HI- there is a significant relationship between independent and dependent variable.

Hypothesis 2: It has been seen above that there is a significant and positive relationship among firm size, profitability and dividend payout ratio. So, it means that with the increase in the firm size and profitability there will also be increase in the dividend payout ratio. Hence the null hypothesis is rejected in case of EPS and profitability while in the case of other variables null is accepted and HI rejected because of their insignificant relationship among them.

Ho- if the company has the more liquid assets, profits, earning per share, leverage and big company size then its capacity to pay dividends will not increase.

HI- if the company has the more liquid assets, profits, earning per share, leverage and big company size then its capacity to pay dividends will increase.

\subsection{Oil Sector}

Oil sector regression results have shown in Table IX. It is found that there is a statistically significant and positive relationship between the earning per share and dividend payout ratio. It means that the companies with good EPS tend to provide more dividends. While the relationship among sales, liquidity and dividend payout ratio is positive and insignificant. Furthermore, there is a negative but insignificant relationship between the profitability and leverage. Here the effect of the independent variable over the dependent variable is shown by the $\mathrm{R}$ square value. Dividend payout ratio takes about $11 \%$ affect from the independent variables. The regression equation would be.

$\mathrm{CG}=* \beta 1-1.050+\beta 20.004+\beta 3-0.07+\beta 41.07+\beta 50.001+$

$\mathrm{e}$
Table IX. Pooled least square regression results-Oil Sector.

\begin{tabular}{lllll}
\hline Variable & Coefficient & Std. Error & t-Statistic & Prob. \\
\hline FS & 1.070 & 3.200 & 0.333 & 0.741 \\
EPS & 0.001 & 0.001 & 1.325 & 0.053 \\
LVRG & -0.078 & 0.087 & -0.896 & 0.376 \\
PFBTY & -1.050 & 0.000 & -0.048 & 0.962 \\
LQTY & 0.004 & 0.012 & 0.349 & 0.729 \\
R-squared & 0.012 & & & \\
Mean D. variable & 0.039 & & & \\
S.D. dependent Var. & 0.104 & & & \\
\hline
\end{tabular}

Hypothesis 1: Here when we compare the $\mathrm{p}$ value of EPS with the alpha value then we conclude that there is a significant relationship between EPS and dividend payout ratio. Hence the null hypothesis in case of EPS is rejected and $\mathrm{HI}$ is accepted but in case of other variables null hypothesis is accepted and $\mathrm{HI}$ is rejected.

Ho- there is no significant relationship between independent and dependent variable.

H1- there is a significant relationship between independent and dependent variable.

Hypothesis 2: It is found above that there is a significant and positive relationship between the EPS and dividend payout ratio. It means that with the good EPS companies in the oil sector tend to offer more dividends. Hence the null hypothesis is rejected and HI is accepted in case of EPS. While in case of other variables null hypothesis is accepted and $\mathrm{Hi}$ is rejected because there is an insignificant relationship.

Ho- if the company has the more liquid assets, profits, earning per share, leverage and big company size then its capacity to pay dividends will not increase.

HI- if the company has the more liquid assets, profits, earning per share, leverage and big company size then its capacity to pay dividends will increase.

\subsection{Relationship between Dividend Payout Ratio (DPR) and Company Growth (CG)}

Here to analyse the relationship between DPR and CG. Pooled Ordinary least square was used and it is found that there is a significant relationship between the dividend payout ratio and company growth. It shows that when there will be positive change in the DPR then it would affect the company growth positively. More precisely, it is observed that the companies which offer consistent dividends, their sales volume also takes a positive effect. It is easy for those companies to attract foreign investment.

Here, $\mathrm{R}$ square value is 0.104 which means that dependent variable takes affect from independent variable (DPR) about $10 \%$.

Table X. Ordinary least square results $-D P R$ and $C G$.

\begin{tabular}{lllll}
\hline Variable & Coefficient & Std. Error & t-Statistic & Prob. \\
\hline DPR & 0.580 & 10.319 & 0.783 & 0.000 \\
R-squared & 0.104 & & & \\
Mean D. variable & 6.667 & & & \\
S.D. dependent Var. & 0.946 & & & \\
\hline
\end{tabular}


Hypothesis 3: When we compare the p value (0.00) with the alpha value $(0.05)$ then we conclude there is positive and statistically significant relationship between the dividend payout ratio and company growth. So the null hypothesis is rejected and the Hi is accepted.

Ho- The positive change in dividend payout ratio will not affect the company growth positively.

HI- The positive change in dividend payout ratio will affect the company growth positively.

\section{Conclusion}

It is concluded from the current research that generally liquidity, earning per share, leverage, firm size and profitability effect positively dividend payout ratio in the nonfinancial companies enlisted in the Karachi stock exchange (KSE) But when we analyse the relationship between the variables sector wise, it is found that some of the variables have significant affect while the others have insignificant like in Energy sector Profitability, firm size and liquidity; In Cement sector Firm size, Earning per share, leverage and profitability; In Sugar sector leverage and liquidity; In Oil sector firm size, leverage, profitability, and liquidity do not have significant correlation with dividend payout ratio. Several investigations have been done so far on dividend payout ratio and its determinants like Najjar (2009) investigated in Jordan and concluded that companies like in the developing countries take influence from the firm size over dividend payout decisions. Perretti, Allen \& Weeks, (2013) concluded that the firm size partially explains the dividend policies. Kun Li and Chung-Hua (2012) asserted that firm's profitability and size significantly affect the payout ratio. John and Muthusamy (2010) investigated in India and found that companies tend to pay more dividends with high leverage.

When the dividend payout ratio is regressed over the company growth then we found that there is a positive and significant relationship between the dividend payout ratio and future company growth. Twaijry also conducted research in 2007 and found that DPR positively affect the company's future growth. Nissim and Ziv (2001) concluded that the change in dividends positively related with the future earnings.

\section{References}

[1] Abor, J. \& Fiador, V. (2013). "Does corporate governance explain dividend policy in Sub-Saharan Africa?" International Journal of Law and Management, Vol. 55, Pp.201 - 225

[2] Abor, J., \& Bopkin, G. A. (2010). Investment opportunities, corporate finance, and dividend payout policy: Evidence from emerging markets. Studies in Economics \& Finance, Vol. 27, Pp. 180-194.

[3] Al - Yahyaee, K. H., Pham, T., \& Walter, T., (2010) "Dividend stability in a unique environment", Managerial Finance, Vol. 36, Pp. 903 - 916
[4] Al- Najjar B. (2009), "Dividend Behavior and Smoothing: New Evidence from Jordanian Panel Data", Studies in Economics and Finance, Vol. 26, No. 3, Pp.: 182-197.

[5] Ahmed, H., \& Javid, A., Y., (2009), Dynamics and determinants of dividend policy in Pakistan', "International research journal of finance and economics", Vol.28, Pp. 56-61

[6] Aivazian, V., Booth, 1., \& Cleary, S., (2003), Do emerging market firms follow different dividend Policies from us firms?, "Journal of financial research", Vol. 26, No. 3, Pp. 371-87.

[7] Amidu, M., \& Abor, J., (2006). Determinants of dividend payout ratios in Ghana, "The journal of risk finance", Vol. 7, No. 2, Pp. 136-145, Doi 10.1108/15265940610648580

[8] Desai, M. A., Foley, C. F., \& Hines Jr., J. R., (2001), Repatriation taxes and dividend distortions. National Tax Journal, Vol. 54, Pp. 829-851.

[9] Eriotis, N., (2005). The effect of distributed earnings and size of the firm to its dividend policy, International Business and Economics Journal, Vol. 4, Pp.: 67-74

[10] Essa, M.S., et al, (2012), A worthy factors affecting dividends policy decisions, An empirical study on industrial corporations listed in Amman stock exchange, "Interdisciplinary journal of contemporary research in business", Vol. 4, No 5

[11] Hafeez, A. \& Attiya Y., (2008).Dynamics and determinants of dividend policy in Pakistan evidence from Karachi stock exchange for non-financial listed firms. MPRA paper 37342

[12] Ho, H., (2003), Dividend policies in Australia and Japan, "International advances in economic Research", Vol. 9, No. 2, Pp. 91-100.

[13] John, F., \& Muthusamy (2010), Leverage, growth and profitability as determinants of dividend payout ratio-evidence from Indian paper industry, "Asian Journal of business management studies". Vol. 1, No. 1, Pp: 26-30

[14] Kun L. \& Chung S., (2012), The impact of corporate governance on the relationship between investment opportunities and dividend policy: an endogenous switching model approach, "Asia-pacific journal of financial studies" Vol. 41, Pp.125-145

[15] Komrattanapanya, P., \& Suntrauk, P., (2013). Factors influencing dividend payout in Thailand: A tobit regression analysis, "International journal of accounting and financial reporting", Vol. 3, No. 2, DOI: 10.5296/ijafr.v3i2.4443s

[16] Musa, \& Fodio, I., (2009). The dividend policy of firms quoted on the Nigerian Stock Exchange: An empirical analysis, African Journal of Business Management Vol.3 (10), pp. 555-566, DOI: 10.5897/AJBM09.199

[17] Najjar, B.A., (2009). Dividend behavior and smoothing new evidence from Jordanian panel data, "Studies in economics and finance". Vol. 26, No. 3, Pp. 182-197 DOI: $10.1108 / 10867370910974017$

[18] Nissim, D., \& Ziv, A., (2001). Dividend changes and future profitability, "The journal of finance", No. 6

[19] Nikolaos, E., (2005). The effect of distributed earnings and size of the firm to its dividend policy: Some Greek Data, "International Business \& Economics Journal", Vol. 4, No. 1 
[20] Miller, M. H., \& Modigliani, F., (1961), Dividend policy, growth and valuation of shares, "Journal of business", Vol. 34, No. 4, Pp. 411-33

[21] Perretti, G. F., Allen, M. T., \& Weeks, H. S. (2013). Determinants of dividend policies for ADR firms, Shelton weeks, managerial finance, Vol. 39,No. 12, Pp. 1155-1168 DOI: $10.1108 / \mathrm{mf}-04-2013-0075$

[22] Salam, A., O., A. Masry and S. Elsegini, (2008). Board composition, ownership structure and dividend policies in an emerging market. Managerial Finance, Vol. 34, Pp.: 953-964.
[23] Twaijry, A. A.A., (2007). Dividend policy and payout ratio: evidence from the kualalum pur

[24] Stock exchange, "The journal of risk finance", Vol. 8. No. 4, pp. 349-363, DOI: 10.1108/15265940710777306

[25] Yahyaee, K.H., Pham, T., \& Walter, T., (2010),Dividend stability in a unique environment, Managerial finance, Vol. 36, No. 10, Pp. 903-916, DOI: 10.1108/03074351011070260 